\title{
Stem Cell Research in Pakistan; Past, Present and Future
}

\author{
Sayeda Anum Zahra, Sayed Raheel Muzavir, Sadia Ashraf, Aftab Ahmad \\ National Academy of Young Scientists (NAYS), University of the Punjab, Quaid-i-Azam Campus, Lahore, Pakistan
}

Background and Objectives: Stem cells have proved to have great therapeutic potential as stem cell treatment is replacing traditional ways of treatment in different disorders like cancer, aplastic anemia, stroke, heart disorders. The developed and developing countries are investing differently in this area of research so research output and clinical translation of research greatly vary among developed and developing countries. Present study was done to investigate the current status of stem cells research in Pakistan and ways to improve it.

Results: Many advanced countries (USA, UK and Canada etc.) are investing heavily in stem cell research and treatment. Different developing countries like Iran, Turkey and India are also following the developed countries and investing a lot in stem cells research. Pakistan is also making efforts in establishing this field to get desired benefits but unfortunately the progress is at very low pace. If Government plays an active role along with private sector, stem cell research in Pakistan can be boosted up. The numbers of publications from Pakistan are very less compared to developed and neighboring countries and Pakistan also has very less number of institutes working in this area of research. Conclusions: Stem cells research is at its initial stages in Pakistan and there is great need to bring Government, academia and industry together so they could make serious efforts to promote research in this very important field. This will help millions of patients suffering from incurable disorders and will also reduce economic loss.

Keywords: Stem cells, Publications, Stem cells institute, Pakistan

\section{Introduction}

Researchers are working around the world for the betterment of society. Due to extensive work in almost all area of biological sciences, there is rapid increase in scientific data and especially in area of stem cell biology (1, 2). Stem cells have the capacity to self-renew and generate differentiated cells $(3,4)$. Stem cells are found in most multi-cellular organisms and are characterized by self-re-

\footnotetext{
Accepted for publication February 2, 2015, Published online May 30, 2015 Correspondence to Aftab Ahmad

NAYS Office, STC, University of the Punjab, New Campus, Lahore, Punjab, Pakistan

Tel: +92-300 740 2202, Fax: +92-429230980

E-mail: aftabac@yahoo.com/president@nays.com.pk

(c) This is an open-access article distributed under the terms of the Creative Commons Attribution Non-Commercial License (http://creativecommons.org/ licenses/by-nc/4.0/), which permits unrestricted non-commercial use, distribution, and reproduction in any medium, provided the original work is properly cited.
}

newal potency and clonality. On the basis of potency or differential potential, stem cells can be categorized as totipotent, pluripotent and multipotent (5). Stem cells have the potential to differentiate into wide and diverse range of specialized cell types (fibroblasts, neurons, myocytes etc.) (6). Cells having wider differentiation potential are pluripotent stem cells which are derived from human embryonic stem cells (ESCs). These cells are critically regulated by many transcription factors (TF) such as Oct3/4, Nanog, Sox2, Klf4 and others. Stem cells have the potential to treat many diseases and their treatment potential is increasing with new research methodologies and approaches.

Thomson et al. (1998) developed the first ESCs line back in 1998 and since then there is boom in this area of research as it has enormous potential to be used in area of therapeutics and regenerative medicines (7). The research in area of cell biology started in Pakistan on return of some cell biologists to country (late 80's and early 90s). 


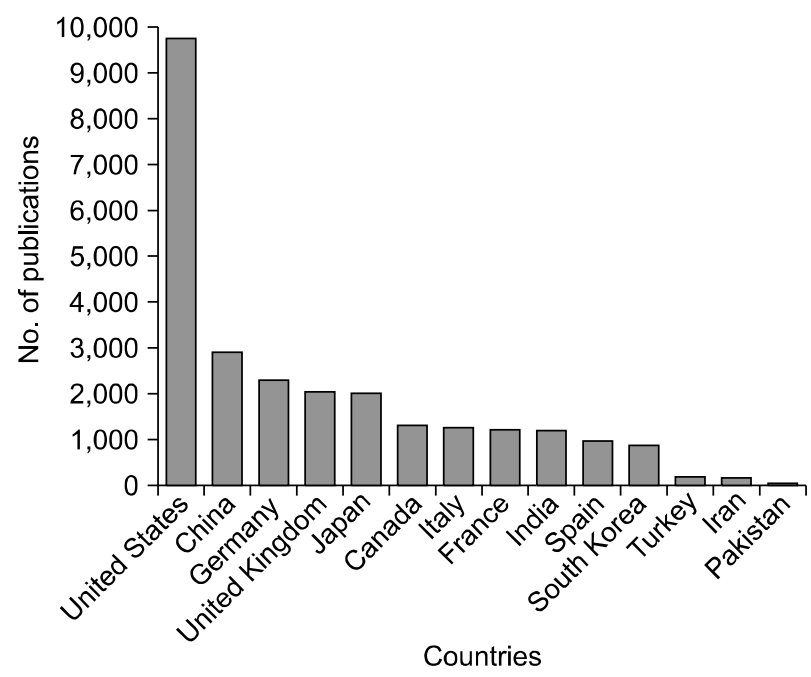

Fig. 1. Publications in cell biology. Comparative analysis of publications from selected countries in the area of cell biology (2012). The maximum documents were produced by USA followed by China and Germany and least by Pakistan.

They tried to establish research laboratories to start this marvelous work in Pakistan. Initially lack of specific equipment's and trained manpower hindered it but with the passage of time laboratories started producing skilled researchers. In addition, stem cells research is in news all the time so it also motivated young researchers to start their career in this important discipline.

There is extensive work and trials in area of basic and applied stem cells research in USA and European countries and some of the Asian countries (Japan, China, Singapore, South Korea etc.) but in most of the developing countries including Pakistan, this area remained neglected and there is very slow progress. In the year 2012, the maximum number of publications in the area of cell biology were produced by USA $(9,750)$ followed by China and Germany and Pakistan published only 37 research articles. The total number of publications from Pakistan were even much less than Turkey and Iran (Fig. 1).

\section{Stem cells research in the region}

In comparison to Pakistan, neighboring countries like Iran and India are very advanced or much ahead in area of stem cells research and transplantation. According to PubMed database, Iran has produced 528 and India 1,091 publications on stem cells from 1999 to February 2013 and form the same time period, publications produced by Pakistan are only $11 \%$ of Iran and $6 \%$ of India. Iran and India are putting lots of effort and money in this area of research that has huge therapeutic applications. Iran is one of the first Muslim countries which are producing ESCs (8). According to the Payv and Iran News, Iran is investing 2.5 billion USD in stem cell research (http:// www.payvand.com/news/08/nov/1059.html) and they have leading institute for stem cell research, "The Royan Institute". The institute is working to investigate the potential of ESCs to differentiate into different types of cells like nerve cell and cardiomyocytes etc. (9). In addition to The Royan Institute, there are other 34 research centers including Shaheed Beheshti University of Medical Sciences and Iran Polymer and Petrochemical Institute which is doing research on use of stem cells as regenerative medicine $(10,11)$. Royan Institute established the first cell therapy pre-hospital in Iran. Another very famous hospital "Shariati Hospital" in Tehran also provides facility for stem cell transplantation to the patients of post-myocardial infarction, multiple sclerosis, cirrhosis, head of femur necrosis, and renal cell carcinoma (12).

India is not behind in this race, as in India more than 40 research institutes, firms and hospitals are involved in stem cell research. Indian government is investing a lot in this regard. During 2004 and 2006, Indian Government invested 8 million USD for stem cell research (13). In India, Indian Council of Medical Research (ICMR) and Department of Biotechnology have formulated the guidelines for stem cell research (14).

ICMR has approved a project on stem cell therapy at the AIIMS Trauma Centre in New Delhi. In 2007, The Madras Institute of Orthopaedics and Traumatology (MIOT) Research Institute was established in India with the collaboration of University Hospital, Zurich, Switzerland, for the regenerative medicine program. MIOT is focusing to get stem cells for the replacement of damaged cells and tissue due to injury or disease. In 2011, steel authority of India has funded a laboratory at the Netaji Subhas Chandra Bose Cancer Research Institute for stem cell research in eastern India. In India, there are many hospitals and centers which provide facility for stem cell based therapy. These hospitals include Tata Memorial (Mumbai), Adyar Cancer Center, Apollo Specialty Center (Chennai), Apollo Hospital, Global Hospital, Nizam's Institute of Medical Sciences (Hyderabad), Narayana Hruduyalaya, Manipal Hospitals, Trinity Hospital (Bangalore), Christian Medical College (Vellore), R\&R Army Hospital, AIIMS (New Delhi), Inlaks Hospital, Armed Forces Medical College (Pune), Sanjay Gandhi PGIMS (Lucknow) and TRICELL, Chennai (A unit of Life Cell International Pvt. Ltd) (15). These centers provide even cost effective treatment than the European and American centers which is greatly facilitating medical tourism in the country. 


\section{Stem cells research work globally}

As mentioned previously, lot of research work is going on all across the world and especially in developed countries on stem cells. The research and clinical applications of stem cells involving human subjects are strictly regulated with country specific details mandated by religious and social mores. A global report on stem cells have been produced in 2012 by Global Industry Analysts (GIA) and according to this report, till 2017, stem cell research market will reach 3.2 billion USD (16). Another world stem cell report was produced by Genetics Policy Institute (GPI) in 2012 which clearly highlight the scope and huge market of the field in future.

In USA, despite the debate of ethical issues related to stem cell in 2011, NIH has funded 1.2 billion USD for stem cell research. About 123 million USD were invested for ESCs only. According to the ISI (institute for scientific information) web of science, US produced more than 4,000 publications on stem cells in 2011 (17). Along with USA, Canada is also performing well in this field. It has strong public support for stem cell research and also has strong collaborations with other countries in this field. Its public health care system is very well suited for clinical trials. Canada has been recognized as world leader in the research for hematopoietic and cancer stem cells (18).

UK government has a huge support for stem cell research. It is focusing to achieve clinical translation of advanced stem cell therapies (19). In UK, European Union invested $€ 107$ million ( $£ 86$ million) for stem cell research (20). UK Research Council's invested £25 and Biomedical Catalyst Fund invested $£ 180$ for stem cells (19). In South Korea, ministry of health invested 29 million USD for stem cells research in 2012. It was four times the amount that was invested in 2011 (21). Sweden has derived more than 50 human ESCs line since 2002 (22) and Brazil established its first stem cell line in 2008. According to reports, Brazil has invested more than 50 million USD for stem cell research (23). In Malaysia, a research group Manipal is investing about RM30 million for stem cell research. In total, Malaysia is investing US\$157 million per year. Unfortunately, in comparison to these countries Pakistan is spending fraction of amount in this important area of research and technology.

Stem cell, for the treatment of various diseases has generated remarkable excitement among researchers and scientists (24). In developed countries, adult stem cells have been used to treat various heart and liver diseases etc. (25). This has given hope to patients and now different stem cells centers and hospitals have started treatment and clinical trials (Boston's children hospital, John Hopkins Hospital, Brain Storm cells, Harvard Medical Center, Euro Stem Cells etc.). In Pakistan millions of people are suffering from diseases such as leukemia, anemia, thalassemia and immune deficiencies so patients are waiting to receive new treatments to cure diseases. As the above mentioned disease can be treated by stem cells therapy so this field has great potential in Pakistan. It is hoped that stem cells can be used to re-grow or regenerate the damaged or dead cells in the infected areas or by stem cell transplant that will be the replacement of diseased cells with healthy cells (26). For all this to happen, there is great need to develop center of excellence in area of stem cells and work should be started in different universities/research centers of the country.

\section{Major research project related to stem cells in Pakistan}

Higher Education Commission (HEC) and Pakistan Science foundation (PSF) has approved many research projects on stem cells recently i.e. Dr. Asmat Salim doing research on "Role of preconditioned and genetically modified mesenchymal stem cells in the regeneration of cardiac tissue" in University of Karachi. Another project by Dr. Fridoon Jawad Ahmad is on "Development of Stem Cell therapy for Patients Suffering from Heart Disease in Pakistan" in King Edward Medical University, Lahore. Ongoing project by PSF is "Preconditioning of the stem and progenitor cells to increase their cardiomyogenic potential" (27). Besides this, there are few other projects which are going on in collaborations with American and European universities and research institutes and Pakistani researchers visit those labs and work there.

\section{Stem cells research institutes in Pakistan}

As stem cells have created a great hype all over the world so stem cells research institutes/centers are also increasing in Pakistan. There is no specific institute or center that is fully dedicated for stem cells research but there are many institutes which have dedicated labs for stem cells research. The major centers in Pakistan that are working in area of stem cells include, Centre of excellence in molecular biology (CEMB), Center for Advanced Molecular Biology (CAMB), Dr. Punjwani Center for Molecular Medicine and Drug Research (University of Karachi), Shahid Zulfiqaar Ali Bhutto Institute of Science and Technology (SZABIST), Lahore University of Management Sciences (LUMS), Quaid-i-Azam University, King 
Table 1. Stem cells research institutes and their websites

\begin{tabular}{cll}
\hline Serial $\#$ & & \multicolumn{1}{c}{ Institute/Hospitals } \\
\hline 1. & Centre of Excellence in Molecular Biology (CEMB) & Website link \\
\hline 2. & Center for Advanced Molecular Biology (CAMB) & www.camb.edu.pk \\
3. & Dr. Punjwani Center for Molecular Medicine and Drug Research, Karachi. \\
4. & Shahid Zulfiqaar Ali Bhutto, Institute of Science and Technology (SZABIST) & www.iccs.edu \\
5. & Lahore University of Management Sciences (LUMS), Lahore & www.szabist.edu.pk \\
6. & King Edward Medical University (KEMU) Lahore, & www.lums.edu.pk \\
7. & Quaid-i-Azam University, Islamabad & www.kemu.edu.pk \\
8. & Pakistan Institute of Medical Sciences (PIMS), Rawalpindi & www.qau.edu.pk \\
9. & Atta ur Rehman School of Applied Biology (ASAB), NUST, Islamabad & www.pims.edu.pk \\
& & UTIONSt.nust.edu.pk/INSTIT \\
10. & Agha Khan University (AKU), Karachi & www.aku.edu \\
11. & Armed Forces Institute of Pathology, Rawalpindi & www.pnac.org.pk \\
12. & School of Biological Sciences, University of the Punjab, Lahore & www.pu.edu.pk \\
13. & National Institute of Blood Disease and Bone Marrow Transplantation (NIBD), Karachi & (http://www.nibd.edu.pk) \\
14. & CryoCell Pak & (www.cryocell.com.pk). \\
\hline
\end{tabular}

Edward Medical University (KEMU) Lahore, Pakistan Institute of Medical Sciences (PIMS) Rawalpindi, Atta ur-Rehman School of Applied Biology (NUST, Islamabad), Agha Khan University (AKU), Armed Forces Institute of Pathology (AFIP) and School of Biological Sciences (University of the Punjab) etc. There are also some private hospitals which are working in this area and the most famous hospital is National Institute of Blood Disease and Bone Marrow Transplantation (NIBD), Karachi. There is also a private center (CryoCell Pak), collecting and storing umbilical cord blood (UCB) so stem cells from UCB could be used later in life when required (Table 1).

\section{Basic and applied stem cells research in Pakistan}

As stem cells can proliferate without differentiation and maintain pluripotency so these are very important tool for the treatment of many types of degenerative diseases and injuries like spinal cord injury, type-1 diabetes, myocardial infarction, thalassemia etc. (28). To cure these types of conditions, ESCs are differentiated into specific cell types (neurons, cardiomyocytes etc.). Some ethical concerns and tissue rejection after transplantation are major obstacles for stem cell transplantation (29,30). Many laboratories in the above mentioned institutes are working on basic stem cells research (establishment of stem cell lines, effect of different drugs and chemical on growth and properties of stem cells etc.) (31-33).

The program of stem cell transplantation is new in Pakistan as it started over a decade ago. For thalassemia and aplastic anemia, allogenic transplantation has been established at some of the centers mentioned below in
Pakistan. But certain autologous activities have to be done for the treatment of myeloma and lymphoma (34). In addition, stem cell transplantation is being used to treat certain fetal hematological diseases. In October 1995 Dr. Tahir Shamsi and his team started stem cell transplantation at Dr. Ziauddin hospital. They used this stem cell therapy in a patient of AML (Acute Myeloid Leukemia). Later in 1999, allogeneic BMT (Bone marrow transplant) was started at Bismillah Taqee Institute of Health Sciences and Blood Diseases Centre, Karachi. In 2001, the Armed Forces Bone Marrow Transplant Centre started functioning (35) and since then, over 350 allogeneic stem cell transplants have been carried out in these two centers. Unfortunately, post-transplant infectious complications occurred in treatment of various malignant and non-malignant hematological disorders by allogenic stem cell transplants (35). Agha Khan Hospital, as third center started the stem cell transplantation facility (36).

The main target diseases for transplant are aplastic anemia, $\beta$-thalassemia major and hematological malignancies. HLA-identical sibling donors provide stem cells for the recipient. In $70 \%$ of cases, a matched donor is identified (36). Children Hospital Lahore is also going to start bone marrow transplantation facility very soon.

\section{Stem cells research output from Pakistan}

From Pakistan total 72 articles have been published in PubMed so far on stem cells. Till 2003, only 16 articles were published but after that quantity of publications increased as research on stem cells accelerated in Pakistan. In 2004, 2; 2005, 6; 2006, 2; 2007, 7; 2008, 6; 2009, 4; 2010, 


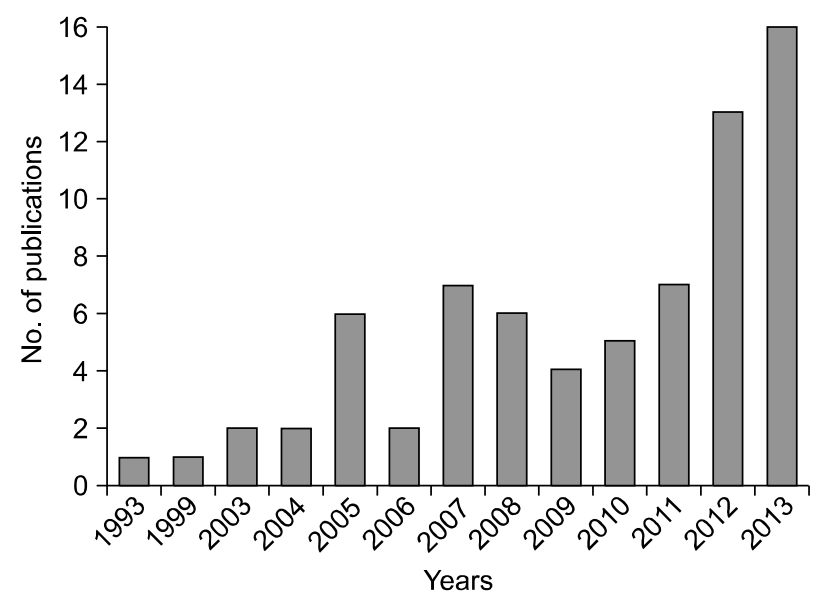

Fig. 2. PubMed publications from Pakistan related to stem cells research from 1993 to 2013.

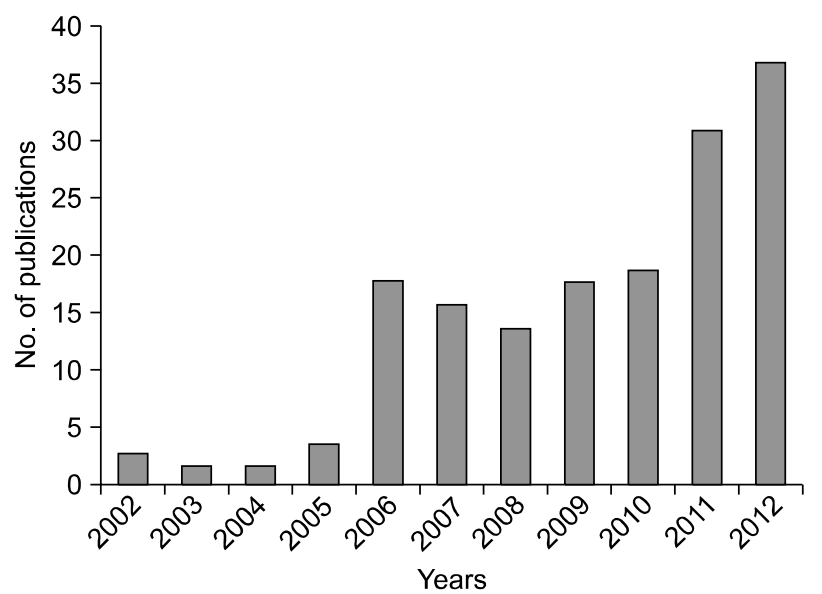

Fig. 3. Total numbers of publications in area of cell biology from Pakistan (2002 to 2012).

Table 2. Events organized in Pakistan related to stem cells research

\begin{tabular}{|c|c|c|c|}
\hline Sr. \# & Title & Organizer & Date \\
\hline 1. & $\begin{array}{l}\text { Workshop on Clinical Hematopoietic } \\
\text { stem cell }\end{array}$ & $\begin{array}{l}\text { National Institute Of Blood Diseases \& Bone } \\
\text { Marrow Transplantation (NIBD), Karachi }\end{array}$ & 1 2 October 2010 \\
\hline 2. & $\begin{array}{l}\text { Conference on "role ofcellin animal } \\
\text { sciences" }\end{array}$ & $\begin{array}{l}\text { (International) University of Veterinary and animal } \\
\text { sciences }\end{array}$ & 4 5 December, 2009 \\
\hline 3. & $\begin{array}{l}\text { Workshop on "Ethical Issues Related to } \\
\text { Work on stem cells" }\end{array}$ & $\begin{array}{l}\text { (National) National Centre of Excellence in Molecular } \\
\text { Biology, University of the Punjab, Lahore, Pakistan }\end{array}$ & 19 20 March, 2009 \\
\hline 4. & $\begin{array}{l}\text { Seminar on Stem Cell transplantation: } \\
\text { Summary of current status and prospects } \\
\text { in low-resource settings. }\end{array}$ & PIMS-Islamabad & $2^{\text {nd }}$ July, 2008 \\
\hline 5. & Ethics of stem cell Research. & $1 \mathrm{~V}^{\text {th }}$ Symposium of $\mathrm{NICH}$, Karachi & $27 \sim 29$ January, 2008. \\
\hline 6. & Seminar on Stem Cell Transplantation & Rawalpindi & 6 7 March, 2006 \\
\hline 7. & $\begin{array}{l}\text { "Stem Cell Research and Cloning: Science, } \\
\text { Ethics and Religious Perspectives" }\end{array}$ & Karachi & $13^{\text {th }}$ August, 2005 \\
\hline 8. & $\begin{array}{l}\text { An international training symposium } \\
\text { and workshop on stem cell }\end{array}$ & CEMB-COMSTECH (CPC) & 01 12 December, 2004 \\
\hline 9. & $\begin{array}{l}\text { Workshop onCell: A BEACON FOR } \\
\text { HUMAN ORGAN REPAIR" }\end{array}$ & $\begin{array}{l}\text { National Centre of Excellence in Molecular } \\
\text { Biology, University of the Punjab, Lahore }\end{array}$ & 1 13 December, 2003 \\
\hline 10. & Stem cell workshop & $\begin{array}{l}\text { COMSTECH and Center of Excellence in } \\
\text { Molecular Biology, Lahore, Pakistan. }\end{array}$ & 2003 \\
\hline
\end{tabular}

5 and in 20117 articles were published. But in 2012 number of publications increased and total 13 articles were published in PubMed journals. In 2013, 16 articles were published according to PubMed (Fig. 2). The total number of publications in area of cell biology from 2002 to 2012 are given in Fig. 3 and it can be clearly seen that there is gradual increase in number of publications from 2009 to 2012 (Fig. 3).

\section{Stem cells related activities in Pakistan}

In order to promote research and collaboration, differ- ent stem cells research related events were organized in Pakistan. The detail of some of the events is given below (Table 2). This is list of some of the main events that were organized over the years but there were many others small activates (lectures and seminars) which were also organized by different departments of universities and research institutes.

\section{Major challenges}

There are many hurdles and obstacles in the growth of transplant medicine i.e. poor transfusion services, lack of 
skilled human resources, poor socioeconomic status, financial limitations and difficulty in keeping pace with technological advancement. There is need of government support to strengthen the existing facilities and for the development of more centers for research and translational work. In addition, private sector should also be promoted so along with government, private sector could also start research and clinical therapies in area of stem cells. International collaborations with advanced centers can be really helpful in this regard.

Due to technological hurdles and cost, the benefits of stem cell transplant is not reaching to common man. Certain viral, fungal and bacterial infections like tuberculosis, malaria and hepatitis $\mathrm{B}$ and $\mathrm{C}$ are also special challenges to transplant teams. The areas that need attention are marrow donor registry and cord blood banks. Again government provided no support to stem cell transplantation program.

In Pakistan, there were no banks for the storage of cord blood but recently CRYOCELL PAKISTAN is offering services for extraction and storage of stem cells. This is a good initiative as cord blood stem cells banks are present in almost all the developed countries of the world and now many developing countries are also making arrangements for storage of stem cells. CRYOCELL Pakistan has an affiliation with an institute in USA.

Beside research work in Pakistan, there is also need to improve social services in the country to educate the patients and their families to comply with treatment during the post-transplant period $(35,36)$.

\section{Recommendations}

Some of the suggestions to promote both basic and applied stem cells research in Pakistan are given below.

There should be two or more big and independent research centers in Pakistan in area of stem cell biology. These centers can be established initially in cities like Karachi and Lahore and they should have strong linkage with universities on one hand and hospitals on the other hand.

There are more than 160 universities in Pakistan (http://www.hec.gov.pk/Ourinstitutes/pages/Default.aspx) but only very few of them have stem cells laboratories, so more universities should be facilitated to establish stem cells related research laboratories.

Government should contact the expatriate researchers working abroad in this area of research and should ask them to return to Pakistan with handsome packages and facilities. In addition, more young scientists should be sent abroad as part of HEC foreign PhD program so more capacity building could be done.

There should be strong collaborations with regional stem cells centers (China, Iran, India etc.) as well as with centers in developed countries so there could be ways for better skill development and technology transfer.

The number of laboratories that are already working in this area should be strengthened in Pakistan by offering them more projects and funds. In addition, these laboratories should develop collaboration with hospitals so technology could be translated in clinical centers. Moreover, they should have internship programs with hospitals.

A stem cell society (Pakistan Stem Cells Society (PSCS)) was established back in 2012 (www.stemcell.org.pk) to promote stem cells related research by one of the author of this manuscript. The society needs more attention and should be strengthened to bring all the stem cells researchers on a single platform. The society should arrange a regular yearly meeting/conference and also should start a journal on the subject with international repute.

Hospitals in Pakistan should have collaboration and linkages with hospitals in developed countries so this technology could be clinically translated in Pakistan with more opportunities for young researchers and clinicians for training and education.

There should be more events in research centers and hospitals related to stem cells (seminars, lectures, symposium and workshops) so knowledge, information and expertise could be shared and more interest of young researchers and clinicians could be developed.

Simple and easy to understand information about stem cells and their potential applications should be available on PSCS and research centers (working on stem cells) website, in both English and Urdu language so not only researchers from other science disciplines but also common public could understand about this important research field. In order to promote the field, PSCS has already started a facebook page (https:/www.facebook.com/ pages/Pakistan-Stem-Cell-Society-PSCS/448409031891529). The page is getting very good response from public.

Theoratical and practical knowledge related to cell biology and stem cells should be introduced both at graduate and post graduate level so students could get more understanding of the field and could join this interesting field during their research projects.

The private sector should be encouraged to invest in this field so along with government sector some private organization should provide stem cells therapy facilities. This will produce an environment of competition, which will further facilitate research and development. 
In Pakistan there are millions of people who are suffering from different types of diseases and injuries like aplastic anemia, thalassemia, type-1 diabetes, myocardial infarction, myeloma, lymphoma, leukemia, spinal cord injury which can be treated by stem cell therapy and this technology has become a hope for them. The guidelines prepared by Human Organ Transplant Authority (HOTA) is nice initiative (http://www.pmrc.org.pk/stem_cell_ protocol.htm) to regulate stem cells research in Pakistan. The guidelines prepared by HOTA are in accordance with religious sensitivities and cultural norms of Pakistan. HOTA is component of Pakistan Medical Research Council (PMRC) which is main regulatory authority in the area of stem cell and related medical research.

\section{Acknowledgments}

We are thankful to NAYS Pakistan for providing us a platform to promote education, science and technology in Pakistan.

\section{Potential conflict of interest}

The authors have no conflicting financial interest.

\section{References}

1. Luo J, Flynn JM, Solnick RE, Ecklund EH, Matthews KR. International stem cell collaboration: how disparate policies between the United States and the United Kingdom impact research. PLoS One 2011;6:e17684

2. Luo J, Matthews KR. Globalization of stem cell science: an examination of current and past collaborative research networks. PLoS One 2013;8:e73598

3. Weissman IL, Anderson DJ, Gage F. Stem and progenitor cells: origins, phenotypes, lineage commitments, and transdifferentiations. Annu Rev Cell Dev Biol 2001;17:387-403

4. Smith AG. Embryo-derived stem cells: of mice and men. Annu Rev Cell Dev Biol 2001;17:435-462

5. Schöler HR. The Potential of Stem Cells: An Inventory. In: Knoepffler N, Schipanski D, Sorgner SL, editors. Human biotechnology as Social Challenge. 2007. 28

6. Ulloa-Montoya F, Verfaillie CM, Hu WS. Culture systems for pluripotent stem cells. J Biosci Bioeng 2005;100:12-27

7. Thomson JA, Itskovitz-Eldor J, Shapiro SS, Waknitz MA, Swiergiel JJ, Marshall VS, Jones JM. Embryonic stem cell lines derived from human blastocysts. Science 1998;282: $1145-1147$

8. Larijani B, Zahedi F, Malek-Afzali H. Medical ethics in the Islamic Republic of Iran. East Mediterr Health J 2005;11: 1061-1072

9. Baharvand H, Ashtiani SK, Valojerdi MR, Shahverdi A, Taee A, Sabour D. Establishment and in vitro differentiation of a new embryonic stem cell line from human blastocyst. Differentiation 2004;72:224-229
10. Jaenisch R. An American scientist in Tehran. Nat Reports Stem Cells 2007 doi:10.1038/stemcells.2007.105

11. Mirzadeh H, Mohagheghi MA, Ahmadi H, Mirkhani H, Amanpour S, Salehian P. Cartilage tissue engineering for ear as in rabbit model with perforated polyurethane prosthesis: in vivo assay. Iranian Polymer Journal 2000;9:73-80

12. Ghavamzadeh A, Alimoghaddam K, Jahani M, Mousavi SA, Iravani M, Bahar B, Khodabandeh A, Khatami F, Ghaffari F, Jalali A. Stem cell transplantation; Iranian experience. Arch Iran Med 2009;12:69-72

13. Sharma A. Stem Cell Research in India: Emerging Scenario and Policy Concerns. Asian Biotechnology and Development Review 2006;8:43-53

14. Savneet K, Karthac C. Stem cells: Concepts and prospects Current trends in Science. 2009

15. Jotwani G. ICMR-DBT Guidelines for Stem Cell Research. New Delhi: Indian Council of Medical Research; 2012

16. Jose S. Increasing Investment in Stem Cell Technology and Promising Research Outcomes Drives the Stem Cell Research Market, According to New Report by Global Industry Analysts. 2012

17. Kirstin RW, Matthews, Maude LR. World stem cell report. Regen Med 2012;7:126-129

18. Willemse L, Ogbogu U, Johnson S, Rudnicki M. World stem cell report: Canada. Regen Med 2012;7:132-135

19. Emily J, Seymour C. World Stem cell report. Regen Med 2012;7:136-138

20. Qadir Z. UK launches a new centre of excellence for stem cell research. Lancet 2012;380:549

21. Park SB. South Korea steps up stem-cell work: Regenerative medicine gets cash boost but stricter regulations are needed to ensure safety. Nature 2012 doi:10.1038/nature.2012.10565

22. Rodin S, Domogatskaya A, Ström S, Hansson EM, Chien $\mathrm{KR}$, Inzunza J, Hovatta O, Tryggvason K. Long-term self-renewal of human pluripotent stem cells on human recombinant laminin-511. Nat Biotechnol 2010;28:611-615

23. Rosalia MO, Antonio Carlos Campos de Carvalho. World Stem cell report, Brazil. Regen Med 2012;7:144-147

24. Chaudry A. (2004). Stem cell bioengineering. Retrieved February 19, 2008 from http://www.scq.ubc.ca/stem-cellbioengineering

25. Levicar N, Dimarakis I, Flores C, Tracey J, Gordon MY, Habib NA. Stem cells as a treatment for chronic liver disease and diabetes. Handb Exp Pharmacol 2007;(180):243-262

26. Weissman IL. Stem cells: units of development, units of regeneration, and units in evolution. Cell 2000;100:157-168

27. http://www.hec.gov.pk/InsideHEC/Divisions/RND/Researc hGrants/NRPU/Pages/Forms/AllItems.aspx

28. Jackson KA, Majka SM, Wang H, Pocius J, Hartley CJ, Majesky MW, Entman ML, Michael LH, Hirschi KK, Goodell MA. Regeneration of ischemic cardiac muscle and vascular endothelium by adult stem cells. J Clin Invest 2001;107:1395-1402

29. Robertson JA. Human embryonic stem cell research: ethical and legal issues. Nat Rev Genet 2001;2:74-78

30. Spencer DD, Robbins RJ, Naftolin F, Marek KL, Vollmer 
T, Leranth C, Roth RH, Price LH, Gjedde A, Bunney BS, et al. Unilateral transplantation of human fetal mesencephalic tissue into the caudate nucleus of patients with Parkinson's disease. N Engl J Med 1992;327:1541-1548

31. Ahmad A, Ziauddin A, Shakoori AR. Isolation and culture of human amniotic fluid stem cells (AFSCS). Pak J Health Res 2013;1:32-35

32. Khan M, Ali F, Mohsin S, Akhtar S, Mehmood A, Choudhery MS, Khan SN, Riazuddin S. Preconditioning diabetic mesenchymal stem cells with myogenic medium increases their ability to repair diabetic heart. Stem Cell Res Ther 2013;4:58

33. Shakoori A, Ahmad A. Cytotoxic and Genotoxic effects of Arsenic and Lead on Human Adipose Derived Mesenchymal
Stem Cells (AMSCs). J Stem Cells Regen Med 2013;9:29-36 34. Farzana T, Shamsi TS, Irfan M, Ansari SH, Baig MI, Shakoor N. Allogeneic peripheral blood stem cell transplantation for aplastic anaemia: a single centre experience. J Pak Med Assoc 2003;53:381-384

35. Ullah K, Raza S, Ahmed P, Chaudhry QU, Satti TM, Ahmed S, Mirza SH, Akhtar F, Kamal K, Akhtar FM. Post-transplant infections: single center experience from the developing world. Int J Infect Dis 2008;12:203-214

36. Shamsi TS, Hashmi K, Adil S, Ahmad P, Irfan M, Raza S, Masood N, Shaikh U, Satti T, Farzana T, Ansari S. The stem cell transplant program in Pakistan--the first decade. Bone Marrow Transplant 2008;42 Suppl 1:S114-S117 